\title{
Kinetics of Proteoglycans and Cells in Growth Plate of Normal, Diabetic, and Malnourished Rats
}

\author{
I. AXELSSON, J. C. PITA, D. S. HOWELL, R. LORENTZON, I. BERMAN, AND L. BOQUIST \\ University of Miami School of Medicine, Miami, Florida [I.A., J.C.P., D.S.H., R.L., I.B.]; and University of \\ Umeå, Umeå, Sweden [R.L., L.B.]
}

\begin{abstract}
The metabolism of proteoglycans in normal growth plate and the changes in growth plate morphology induced by diabetes and malnutrition were studied in rats. The proteoglycans had a significantly faster turnover (halflife measured with $\left[{ }^{35}\right.$ S]sulfate labeling: $25-30 \mathrm{~h}$ ) than the cells in the growth plate. Morphometric studies showed significant reductions of cell number, zone height, and $\left[{ }^{3} \mathrm{H}\right]$ thymidine incorporation in growth plates from rats with untreated streptozotocin-induced diabetes compared to normal rats. Similar, although less pronounced alterations were observed in malnourished, nondiabetic rats. Disaggregation and degradation of proteoglycans are probably necessary prerequisites for calcification. Our data indicate that the proteoglycans are in a dynamic state of rapid biosynthesis and degradation throughout the growth plate with a shift in the balance at the calcification front toward less synthesis and more degradation. (Pediatr Res 27: 4144, 1990)
\end{abstract}

Longitudinal growth of tubular bones takes place by cell divisions and synthesis of extracellular matrix by the chondrocytes of the growth plate. This process is regulated by several hormones, including growth hormone, insulin, and somatomedins $(1-7)$. The stimulation of growth by insulin $(4-7)$ is clinically demonstrated by the retarded growth that may occur in insulinopenic diabetic children (8).

Bone formation is preceded by provisional calcification of the cartilage matrix. Most investigators have found that the concentration of proteoglycans decreases during calcification, which may suggest that calcification is inhibited by proteoglycans ( 9 12). The transformation of the large, dense proteoglycan aggregates in the proliferative and upper hypertrophic zone to the relatively small, star-like proteoglycan aggregates in preparations from rabbit growth plate (13) has been suggested to allow the movement of calcium and phosphate ions and the growth of mineral clusters (14). Shepard and Mitchell (15) did not find any decrease in proteoglycan concentration during calcification but described that mineralization starts with star-shaped proteoglycan aggregates as templates.

We have described profound changes of proteoglycan metabolism in the growth plate of diabetic rats, namely a complete absence of large proteoglycan aggregates and a sharp reduction of the synthesis of sulfated glycosaminoglycans, the chains of

Received June 29, 1989; accepted August 30, 1989

Correspondence I. Axelsson, M.D., Department of Pediatrics, County Hospital, S-831 83 Östersund, Sweden.

Supported by grants from the United States Public Health Service (Fellowships 1-F05-TW02601-01 and 5-F05-TW02601-02 to I.A.), Veterans Administration research funds, and the research funds of the Östersund County Hospital. which were shorter than in normal rats (5). Insulin-treated diabetic rats and malnourished nondiabetic rats showed changes in proteoglycan metabolism that were intermediate between normal and diabetic rats.

Our study was designed to investigate the turnover of growth plate proteoglycans in normal rats and the morphologic changes of growth plate in diabetes and malnutrition. A preliminary report has been published (16).

\section{MATERIALS AND METHODS}

Studies of ${ }^{35}$ S/-labeled proteoglycans. Twenty 25 -d-old male Sprague-Dawley rats (Charles River Breeding Laboratories, Wilmington, MA) were injected with carrier-free $\mathrm{Na}_{2}\left[{ }^{35} \mathrm{~S}_{\mathrm{SO}_{4}}(3\right.$ $\mu \mathrm{Ci} / \mathrm{g}$ body wt; $3 \mu \mathrm{Ci}=111 \mathrm{kBq}$ ) into the tail vein and killed 2 , $24,48,72$, or $96 \mathrm{~h}$ later by intracardial injection of sodium pentobarbital. The growth plate and adjacent calcified metaphyseal tissue were dissected from the proximal end of each tibia and pieces were used for autoradiography or extraction of proteoglycans.

Autoradiography was performed as described by Campo and Dziewiatkowski (17). Extraction and characterization of proteoglycans were performed in the following way: Pieces of cartilage were immediately after dissection placed in ice-cold $4 \mathrm{M}$ guanidine- $\mathrm{HCl}$ in $0.25 \mathrm{M}$ sodium acetate, $\mathrm{pH} 5.8$ (about $1 \mathrm{~mL} / 20 \mathrm{mg}$ wet tissue) containing protease inhibitors (5). The suspension was dialyzed against $20 \mathrm{vol}$ of the extraction solution with magnetic stirring at $-12^{\circ} \mathrm{C}$ for $24 \mathrm{~h}$ and then centrifuged at $8^{\circ} \mathrm{C}$ in a Beckman SW 50.1 rotor at $15000 \mathrm{rpm}$ for $10 \mathrm{~min}$. The insoluble residue was digested with $1 \mathrm{~mL} 88 \%$ formic acid at $90^{\circ} \mathrm{C}$ for $15 \mathrm{~min}$.

A portion of the supernatant, which contained dissociatively extracted proteoglycans, was applied to a dissociative Sepharose CL-2B column (elution buffer = extraction buffer), or brought to associative conditions by dialysis at $4^{\circ} \mathrm{C}$ for $6-8 \mathrm{~h}$ against 10 vol of associative solution (extraction solution minus guanidine$\mathrm{HCl}$ ) and then immediately applied to an associative Sepharose $\mathrm{CL}-2 \mathrm{~B}$ column (elution buffer $=0.5 \mathrm{M}$ guanidine- $\mathrm{HCl}-0.05 \mathrm{M}$ sodium acetate ( $\mathrm{pH}$ 5.8) with protease inhibitors) (5). The partition coefficient $k_{d}$ and the ratio of elution volume $\left(V_{1}\right)$ to total included volume $\left(V_{1}\right)$ were computed for various elution volumes. $\mathrm{k}_{\mathrm{d}}$ is defined by the equation

$$
\mathrm{k}_{\mathrm{d}}=\left(\mathrm{V}_{\mathrm{e}}-\mathrm{V}_{\mathrm{o}}\right) /\left(\mathrm{V}_{\mathrm{l}}-\mathrm{V}_{\mathrm{o}}\right) ; \mathrm{V}_{\mathrm{o}}=\text { void vol }
$$

Another portion of the dialyzed extract was kept at $-20^{\circ} \mathrm{C}$ overnight and subjected to transport centrifugation (18) the next day. Portions from the digested extraction residues and the clarified extracts, and the fractions from gel chromatography and ultracentrifugation, were diluted with Aquasol and the radioactivity was measured by liquid scintillation spectrometry (5). 
Extraction yield of proteoglycans was computed from the radioactivity measurements on extract and residue.

Quantitative morphologic studies. Thirty male Sprague-Dawley rats were 5 wk old when the experiments started (day 0 ); they were killed $8 \mathrm{~d}$ later ( $\mathrm{d}$ 8). Diabetes was induced in 15 rats on $\mathrm{d}$ 0 by a single intravenous dose of streptozotocin (Sigma Chemical Co., St Louis, MO) $(19,20)$ as described previously (5). Ten rats served as controls. They were fasted, anesthetized, and injected with the buffer without streptozotocin.

Five diabetic rats were treated with daily subcutaneous injections of NPH-insulin (protamine insulin; $1 \mathrm{IU} / 100 \mathrm{~g}$ body wt) (5). Malnutrition was induced in another five rats by feeding them water ad libitum but a reduced number of pellets (Purina Laboratory Chow, Purina, St. Louis, MO) during d 0-8. The number of pellets was adjusted so that these rats showed the same weight development as the diabetic rats, i.e. a constant or slightly decreasing weight. All other rats were fed pellets and water ad libitum.

On $\mathrm{d} 8$, all animals were killed by intracardial injection of sodium pentobarbital. The proximal growth plate of each tibia was cut out in its full thickness with a small rim of bone on the epiphyseal and metaphyseal sides. The tissue was immediately fixed at room temperature by immersion into $2.5 \%$ glutaraldehyde in Sörensen's $0.1 \mathrm{M}$ sodium phosphate buffer at $\mathrm{pH} 7.4$ for $3 \mathrm{~h}$ and then rinsed thoroughly in the buffer. The specimens were stored in the buffer overnight at $4^{\circ} \mathrm{C}$, and postfixed the following day in $1 \% \mathrm{OsO}_{4}$ in $0.1 \mathrm{M}$ sodium phosphate, $\mathrm{pH} 7.4$ for $2 \mathrm{~h}$. The tissue blocks were dehydrated through graded concentrations of alcohol and propylene oxide and embedded in Epon 812.

Each growth plate was cut into several semithin $(1 \mu \mathrm{m})$ sagittal sections for light microscopy. The sections exactly perpendicular to the growth plate were stained with toluidine blue. Micrographs were taken at a primary magnification of $40 \times$ and printed at a final magnification of $250 \times$.

In each growth plate, three to five cell columns with the plane of section parallel to the columns were selected for measurement of zone width and cell number. The width of the proliferative zone was measured from the first chondrocyte of the cell column to the level where the cells began to enlarge in size and the width of the hypertrophic zone from the level of enlarging cells to the last hypertrophic chondrocyte at the zone of provisional calcification.

On $\mathrm{d} 8$, five diabetic and five control rats were injected intraperitoneally with $1 \mu \mathrm{Ci} / \mathrm{g}$ body wt $(1 \mu \mathrm{Ci}=37 \mathrm{kBq})$ of tritiated thymidine $(5 \mathrm{Ci} / \mathrm{mmol}=185 \mathrm{GBq} / \mathrm{mmol}$; Amersham International, Bucks., U.K.). These animals were killed $1 \mathrm{~h}$ after injection and the growth cartilage (whole width) of the proximal tibia was rapidly dissected out. Incorporation of $\left[{ }^{3} \mathrm{H}\right]$ thymidine in growth plate chondrocytes and DNA concentrations were determined as described by Weiss and Reddi (21). For comparison of data, Student's $t$ test for unpaired observations was used (22). Data are expressed as mean $\pm \mathrm{SD}$.

\section{RESULTS}

Proteoglycan turnover in normal rats. The $\left[{ }^{35} \mathrm{~S}\right]$-sulfate concentration in the growth plate reached its peak value within $24 \mathrm{~h}$ after sulfate injection (Fig. 1). The elimination of sulfate followed first-order kinetics with a $t^{1 / 2}$ of $25-30 \mathrm{~h}$.

Agarose gel chromatography and transport ultracentrifugation of dissociatively extracted proteoglycans (extraction yield 86$94 \%$ of total tissue $\left[{ }^{35} \mathrm{~S}\right]$ sulfate) did not reveal any differences in molecular size of monomers at various times after $\left[{ }^{35} \mathrm{~S}\right]$ sulfate injection (Fig. 2, broken line; ultracentrifugal data not shown), but the proportion of labeled proteoglycans with low $k_{d}$ values and high apparent sedimentation coefficients in the dialyzed extracts tended to decrease with time (Fig. 3), suggesting a decreasing ratio of proteoglycan aggregates to monomers. In

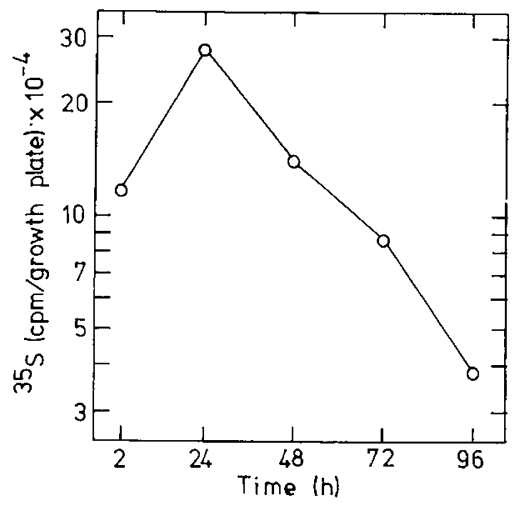

Fig. $1 .{ }^{35} \mathrm{~S}$ radioactivity in growth plates of rats $(n=20)$ at various time intervals after ${ }^{35} \mathrm{~S}$-sulfate injection. The vertical scale is logarithmic.

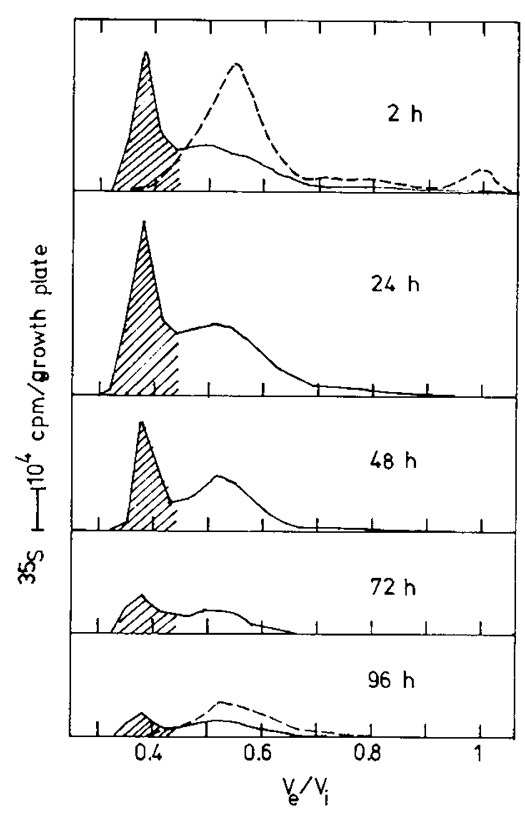

Fig. 2. Chromatography of proteoglycan extracts on associative (solid line) and dissociative (broken line) Sepharose CL-2B columns. The time from injection of ${ }^{35} \mathrm{~S}$-sulfate to death of the rat is shown. The hatched areas show the material eluted in the void volume $\left(k_{d}<0.1\right)$ of the associative column.

repeated experiments, similar elution and centrifugation patterns were consistently observed.

Cell kinetics in normal, diabetic, and malnourished rats. The growth plates of the various experimental groups did not differ from the control group as to general microscopic architecture, i.e. all showed chondrocytes arranged in cell columns that could be divided into resting, proliferative, and hypertrophic zones. In some growth plates of all groups proliferative cell columns occasionally showed focal discontinuity. The resting zone was very narrow in all groups.

The zone width and cell numbers of the proliferative and hypertrophic zones in the various experimental groups are shown in Figure 4, and significant deviations from the control groups are indicated. There was also one significant difference within the experimental groups: Diabetic rats with no insulin treatment had significantly fewer proliferative cells than insulin-treated diabetic rats $(p<0.05)$.

The incorporation of $\left[{ }^{3} \mathrm{H}\right]$ thymidine in control and diabetic growth plates was $996 \pm 45(n=5)$ and $727 \pm 201(n=5) \mathrm{cpm} /$ $\mu \mathrm{g}$ DNA, respectively $(p<0.01)$. An even distribution of $\left[{ }^{35} \mathrm{~S}\right]$ 
sulfate throughout the growth plate was demonstrated by autoradiography (autoradiograms not shown).

\section{DISCUSSION}

Normal growth plate. Boström (23), Bélanger (24), and Campo and Dziewiatkowski $(17,25)$ pioneered studies of proteoglycan metabolism using labeling with $\left.{ }^{35} \mathrm{~S}\right]$ sulfate. The present data on the kinetics of rat growth plate proteoglycans (Fig. 1) may be compared with previous data on rat costal cartilage proteoglycans (23). In both cases, the half peak value and peak value for sulfate concentration in cartilage were reached after 2 and $24 \mathrm{~h}$, respectively, although we do not know the sulfate incorporation e.g. $12 \mathrm{~h}$ after injection. The elimination of sulfate was, however, about 14 times faster in growth plate than in costal cartilage. Approximately $95 \%$ of the sulfate in cartilage is linked to proteoglycans $(5,25)$. We conclude that the proteoglycans in growth plate are in a dynamic state of rapid turnover with a $t^{1 / 2}$ of about 25-30 h. Proteoglycans in the costochondral junctions of immature rabbits also have a $t^{1 / 2}$ of $1-2 \mathrm{~d}(12)$.

Walker and Kember (26) described the cell kinetics in growth plates of proximal tibia from rats of different ages. We have compared their data with ours and conclude that the cells in the upper part of the proliferative zone will reach the zone of provisional calcification after 3-4 d.

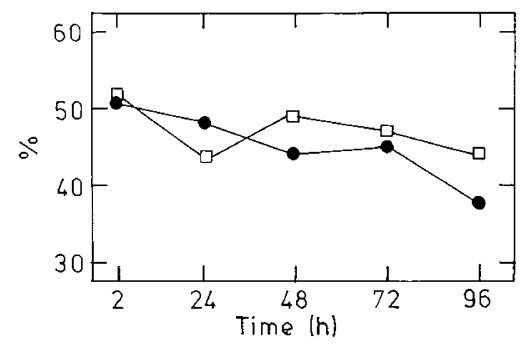

Fig. 3. Proportions of aggregates among $\left[{ }^{35}\right.$ S llabeled proteoglycans at various time intervals after $\left[{ }^{35} \mathrm{~S}\right]$ sulfate injection, measured as percentage of $\left[{ }^{35}\right.$ S]sulfate migrating 1 ) with $\mathrm{k}_{\mathrm{d}}<0.1$ in associative Sepharose CL-2B chromatography (corresponding to hatched area in Fig. 2) (closed circles), and 2) with apparent sedimentation coefficient above $40 \mathrm{~S}$ at transport centrifugation (squares).

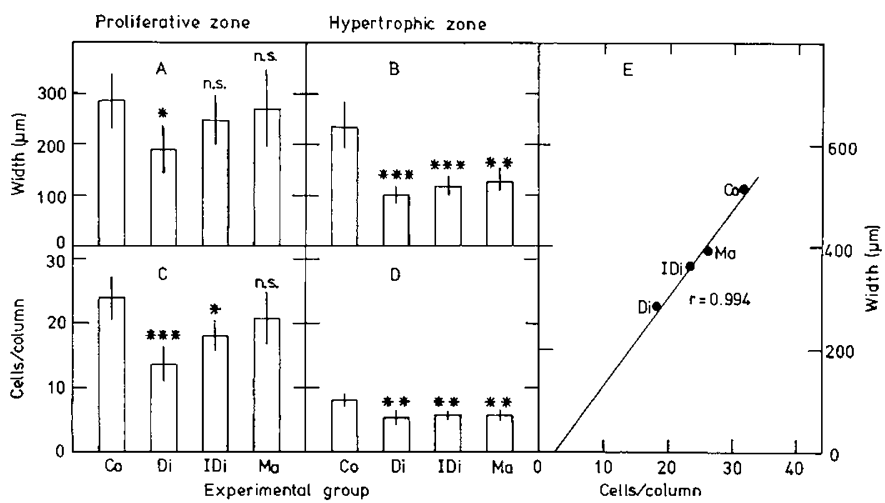

Fig. 4. Morphometry of growth plates: width of $(A)$ proliferative and $(B)$ hypertrophic zones; number of cells per cell column in $(C)$ proliferative and $(D)$ hypertrophic zones. $C o$, control group; $D i$, diabetic rats with no insulin treatment; $I D i$, insulin-treated diabetic rats; $M a$, malnourished rats. Mean values $\pm \mathrm{SD}$ (vertical bars) are shown; each mean value is based on 12 or 15 observations. Statistical significance of the difference between each experimental group and the control group: n.s., not significant; ${ }^{*} p<0.05 ;{ }^{* *} p<0.01 ;{ }^{* * *} p<0.001$. E, correlation between total width and total number of cells per cell column for proliferative zone + hypertrophic zone in the four groups of rats. The regression line (best least squares) and $r$ are shown.
The proteoglycan turnover in normal growth plate thus seems to be significantly faster than the cell turnover. Any segment of the growth plate hence metabolizes its proteoglycans several times before it is reached by the calcification front. This conclusion is strengthened by the even distribution of $\left[{ }^{35} \mathrm{~S}\right]$ sulfate and thus proteoglycan biosynthesis throughout the growth plate in previous (24) and present investigations and by the relatively small differences in gel chromatographic and ultracentrifugal profiles at various time intervals after sulfate injection (Figs. 2 and 3). The straight line in Figure 1 suggests that there is only one major pool of proteoglycans in the growth plate.

Changes in the concentration, tissue distribution, and aggregation of proteoglycans are probably necessary prerequisites for calcification $(9-12,14,15)$. Our data indicate that the breakdown of growth plate proteoglycans is not exclusively localized to the zone of calcification. We believe that the proteoglycans are in a dynamic state of rapid biosynthesis and degradation throughout the growth plate, and that the decrease in proteoglycan concentration at the calcification front is the result of a shift in balance toward less synthesis and more degradation.

Diabetes and malnutrition. A severe disturbance of the proliferative ability of the chondrocytes in diabetic rats is suggested by the decreased uptake of $\left[{ }^{3} \mathrm{H}\right]$ thymidine, the decreased number of cells in the proliferative zone, and the reduction of zone width. Insulin-treated diabetic rats exhibited morphometric parameters qualitatively similar to those of untreated diabetic rats but the changes were less severe.

The appearance and arrangement of the cells within the different zones did not differ between the control group and the experimental groups. This is demonstrated by the good correlation between cell number per cell column and width of the growth plate (Fig. $4 E$ ).

Only small changes of the size of the proliferative zone have previously been observed after interventions that disturb bone growth, such as hypophysectomy, or administration of growth hormone or cortisol (27). Weiss et al. (28) suggest that streptozotocin-induced diabetes of $14 \mathrm{~d}$ duration is associated with only minor morphologic alterations. It is, however, evident from their illustrations that the width of the proximal growth plate of tibia is reduced by approximately $40 \%$ and both the proliferative and hypertrophic zones are thinned. Marked thinning of the proximal growth plate of rat tibia and focal discontinuity of the cell columns were observed in long-term (7 wk) streptozotocin-induced diabetes by Hough et al. (29). Such discontinuity was sometimes observed in the proliferative zone of both diabetic and control rats in the present study. The biologic significance of this finding, if any, is not clear. It may well be an artifact in tissue sections not perfectly parallel to the cell columns.

Insulin treatment for 3-5 wk completely normalized the growth plate in diabetic rats in the study by Hough et al. (29). This was not the case in our study. This difference may be explained by different ages of the animals, different doses of insulin, and different duration of treatment.

The decrease of chondrocyte proliferation reported here and the decrease of proteoglycan biosynthesis reported previously (5) are probably caused by a reduction of the activity of somatomedins. Decreased intracellular concentration of the precursor sugar nucleotides involved in glycosaminoglycan biosynthesis may also play a role for the decrease of proteoglycan biosynthesis (30). Reduction of somatomedin activity is found in experimental diabetes and may be caused by the occurrence of somatomedin inhibitors (31) or lack of stimulation of somatomedin synthesis (7). Decreased stimulation of cartilage by somatomedins due to imbalance between somatomedins and inhibitors of somatomedins is probably a common feature of protein-energy malnutrition and diabetes in children and animals (32). Malnutrition is also associated with low levels of insulin (33).

Despite a similar weight development in our diabetic and malnourished rats, all morphologic changes were significantly more pronounced in diabetic rats in our investigation as was the 
decrease in proteoglycan synthesis in our previous investigation (5). It may be concluded from these quantitative differences that the two conditions affect body weight and cartilage metabolism by a different mechanism.

\section{REFERENCES}

1. Salmon WD Jr, Daughaday WH 1957 A hormonally controlled serum factor which stimulates sulfate incorporation by cartilage in vitro. J Lab Clin Med 49:825-836

2. Lebovitz HE, Eisenbarth GS 1975 Hormonal regulation of cartilage growth and metabolism. Vitam Horm 33:575-648

3. Froesch ER, Zapf J, Audhya TK, Ben-Porath E, Segen BJ, Gibson KD 1976 Nonsuppressible insulin-like activity and thyroid hormones: major pituitarydependent sulfation factors for chick embryo cartilage. Proc Natl Acad Sci USA 73:2904-2908

4. Phillips LS, Vassilopoulou-Sellin R 1980 Somatomedins. N Engl J Med 302:371-380, 438-446

5. Axelsson I, Lorentzon R, Pita JC 1983 Biosynthesis of rat growth plate proteoglycans in diabetes and malnutrition. Calcif Tissue Int 35:237-242

6. Rechler MM, Nissley SP, Roth J 1987 Hormonal regulation of human growth. N Engl J Med 316:941-943

7. Robinson ICAF, Clark RG, Carlsson LMS 1987 Insulin, IGF-I and growth in diabetic rats. Nature 326:549

8. Pond H 1970 Some aspects of growth in diabetic children. Postgrad Med J 46:616-623

9. Howell DS, Carlson L 1968 Alterations in the composition of growth cartilage septa during calcification studied by microscopic x-ray elemental analysis. Expt Cell Res 51:185-195

10. Lohmander S, Hjerpe A 1975 Proteoglycans of mineralizing rib and epiphyseal cartilage. Biochim Biophys Acta 404:93-109

11. Howell DS, Pita JC 1976 Calcification of growth plate cartilage with special reference to studies on micropuncture fluids. Clin Orthop 118:208-229

12. Campo RD, Romano JE 1986 Changes in cartilage proteoglycans associated with calcification. Calcif Tissue Int 39:175-184

13. Axelsson I, Berman I, Pita JC 1983 Proteoglycans from rabbit articular and growth plate cartilage. Ultracentrifugation, gel chromatography, and electron microscopy. J Biol Chem 258:8915-8921

14. Buckwalter JA, Rosenberg L 1986 Structural changes in reassembled growth plate aggregates. J Orthop Res 4:1-9

15. Shepard N, Mitchell N 1985 Ultrastructural modifications of proteoglycans coincident with mineralization in local regions of rat growth plate. $J$ Bone Joint Surg 67-A:455-464

16. Axelsson I, Lorentzon R, Pita JC, Howell DS, Berman I, Boquist L 1985 Kinetics of proteoglycans and cells in growth plate of normal and diabetic rats. Acta Paediatr Scand [Suppl] 322:39 (abstr)

17. Campo RD, Dziewiatkowski DD 1963 Turnover of the organic matrix of cartilage and bone as visualized by autoradiography. J Cell Biol 18:19-29

18. Pita JC, Müller FJ, Oegema T, Hascall VC 1978 Determination of sedimentation coefficient distributions for cartilage proteoglycans. Arch Biochem Biophys 186:66-76

19. Baxter RC, Brown AS, Turtle JR 1980 Association between serum insulin, serum somatomedin and liver receptors for human growth hormone in streptozotocin diabetes. Horm Metab Res 12:377-381

20. Junod A, Lambert AE, Stauffacher W, Renold AE 1969 Diabetogenic action of streptozotocin: relationship of dose to metabolic response. J Clin Invest 48:2129-2139

21. Weiss RE, Reddi AH 1980 Influence of experimental diabetes and insulin on matrix-induced cartilage and bone differentiation. Am J Physiol 238:E200E207

22. Snedecor GW, Cochran WG 1967 Statistical Methods, 6th ed. The Iowa State University Press, Ames, IA

23. Boström H 1952 On the metabolism of the sulfate group of chondroitinsulfuric acid. J Biol Chem 196:477-481

24. Bélanger LF 1954 Autoradiographic visualization of the entry and transit of $\mathrm{S}^{35}$ in cartilage, bone, and dentine of young rats and the effect of hyaluronidase in vitro. Can J Biochem Physiol 32:161-169

25. Campo RD, Dziewiatkowski DD 1961 A consideration of the permeability of cartilage to inorganic sulfate. J Biophys Biochem Cytol 9:401-408

26. Walker KVR, Kember NF 1972 Cell kinetics of growth cartilage in the rat tibia. II. Measurements during aging. Cell Tissue Kinet 5:409-419

27. Kember NF, Walker KVR 1971 Control of bone growth in rats. Nature 229:428-429

28. Weiss RE, Gorn AH, Nimni ME 1981 Abnormalities in the biosynthesis of cartilage and bone proteoglycans in experimental diabetes. Diabetes 30:670677

29. Hough S, Aviolo LV, Bergfeld MA, Fallon MD, Slatopolsky E, Teitelbaum SL 1981 Correction of abnormal bone and mineral metabolism in chronic streptozotocin-induced diabetes mellitus in the rat by insulin therapy. Endocrinology 108:2228-2234

30. Stevens RL, Hascall VC 1981 Characterization of proteoglycans synthesized by rat chondrosarcoma chondrocytes treated with multiplication-stimulating activity and insulin. J Biol Chem 256:2053-2058

31. Phillips LS, Vassilopoulou-Sellin R, Reichard LA 1979 Nutrition and somatomedin. VIII. The "somatomedin inhibitor" in diabetic rat serum is a general inhibitor of growing cartilage. Diabetes 28:919-924

32. Price DA, Wit JM, van Buul-Offers S, Korteland-van Male AM, van RooyenWehmeijer AKM, Hoogerbrugge C, van den Brande JL 1979 Serum somatomedin activity and cartilage metabolism in acutely fasted, chronically malnourished, and refed rats. Endocrinology 105:851-861

33. Hadden DR 1967 Glucose, free fatty acid, and insulin interrelations in kwashiorkor and marasmus. Lancet 2:589-593 